\title{
Pengendalian Gerak Robot menggunakan Semantik Citra Gestur Tangan Manusia
}

\author{
SUSETYO BAGAS BHASKORO', MUHAMMAD AZHAR ABDUL AZIZ² \\ ${ }^{1}$ Teknologi Rekayasa Otomasi, Politeknik Manufaktur Bandung, Indonesia \\ ${ }^{2}$ Teknik Elektromekanik, Politeknik Manufaktur Bandung, Indonesia \\ Email: bagas@ae.polman-bandung.ac.id
}

Received 15 Agustus 2019 | Revised 3 September 2019 | Accepted 15 Oktober 2019

\begin{abstract}
ABSTRAK
Pengendalian robot jarak jauh menjadi sangat dibutuhkan pada bidang otomasi industri. Objektif dari penelitian ini adalah mengembangkan robot lengan beroda pemindah benda menggunakan perintah semantik citra gestur tangan manusia. Evaluasi pada penelitian ini dibedakan menjadi dua kategori yaitu deteksi semantik citra gestur tangan manusia dan manuver gerak bebas robot lengan beroda. Tingkat keberhasilan identifikasi gestur tangan sebesar 77,73\%. Manuver gerak maju memiliki rata-rata error sebesar 4,125\%, gerak mundur sebesar 4,85\%, gerak berputar kiri sebesar 14,36\% dan gerak berputar kanan sebesar $6,66 \%$.
\end{abstract}

Kata kunci: robot lengan beroda, semantik citra, gesture tangan, gerak manuver, Lab-VIEW.

\begin{abstract}
Remote control of the robot became very needed in the industrial automation fields. The research objectives are to develop a driven wheeled arm robot using human hand gesture semantic commands. Evaluation in this research is divided into two categories are the detection of human hand movements and the freedom of motion wheeled arm robots. The successful identification of human hand gestures is $77.73 \%$. The maneuvers has an average error is $4.125 \%$, the backward motion is $4.85 \%$, left rotating motion is $14.36 \%$ and right rotating motion is $6.66 \%$.
\end{abstract}

Keywords: A driven wheeled arm robot, semantic vision, human hand gesture, motion maneuvers, Lab-VIEW 


\section{PENDAHULUAN}

Aktifitas pada logistik manufaktur membutuhkan energi yang besar untuk memindahkan benda dari satu tempat ke tempat lainnya secara berulang, dengan berat benda yang beragam dan jarak perpindahannya yang tidak selalu sama. Oleh karena itu, dibutuhkan teknologi yang dapat meringankan kinerja tersebut salah satunya menggunakan robot lengan beroda yang memiliki kemampuan daya jelajah tinggi. Robot lengan pada penelitian ini memiliki tujuan untuk mengangkat dan memindahkan benda, sementara itu robot menggunakan roda pada penelitian ini memiliki tujuan untuk memudahkan gerak manuver robot, sedangkan semantik gestur tangan digunakan sebagai instruksi untuk mengendalikan gerak robot lengan beroda dari jarak jauh. Ilustrasi dari pengendalian lengan robot beroda pemindah benda menggunakan semantik citra seperti pada Gambar 1 berikut.

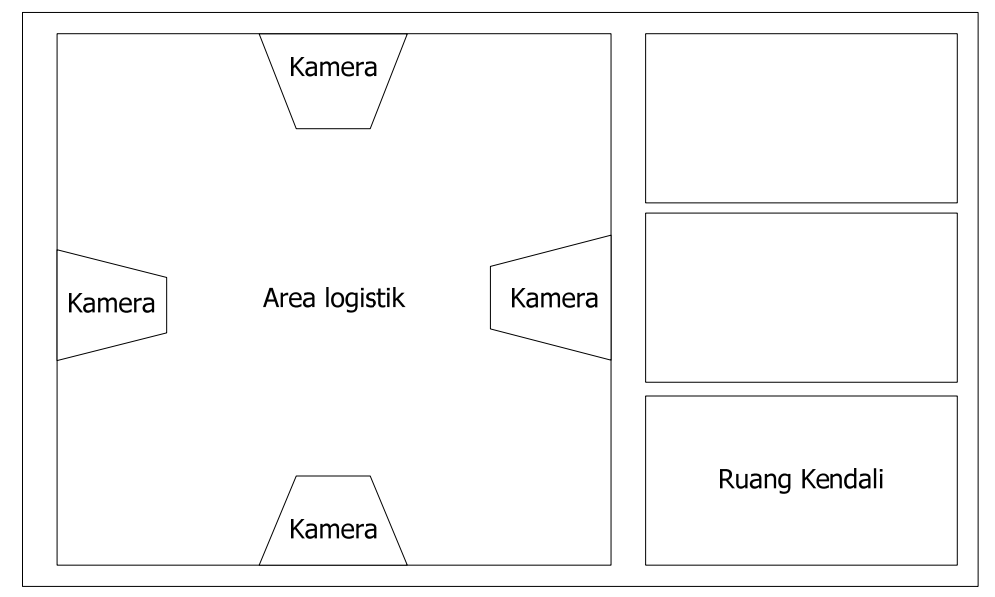

\section{Gambar 1. Ilustrasi Pengendalian Lengan Robot Beroda Pemindah Benda yang Dikendalikan dari Tempat yang Berbeda menggunakan Semantik Citra}

Beberapa penelitian yang terkait dengan robot lengan beroda antara lain pengendalian robot menggunakan sensor accelerometer dan flex yang terpasang pada sarung tangan dan elbow band (Arifin, 2017). Penelitian lainnya adalah pengendalian robot menggunakan sensor accelerometer dan flex untuk mengendalikan lengan robot (Syed, dkk, 2012), penggunaan dua kendali pada penelitian tersebut menandakan kurangnya efisiensi kinerja dari sistem robot.

Penelitian saat ini menggunakan pendeteksian semantik citra gestur tangan manusia yang diambil melalui kamera. Pengambilan gambar dilakukan berkali-kali dalam satu waktu sehingga membentuk sebuah pola perintah semantik untuk menggerakkan gerak robot untuk maju, mundur, belok kiri, belok kanan dan menggerakkan lengannya. Semantik pada penelitian ini mengadopsi dari pemahaman semantik yang dilakukan pada natural language processing yaitu cabang ilmu bahasa yang mempelajari mengenai pengertian kalimat serta ketergantungan arti kata dalam pembentukan kalimat (Riaz \& Girju, 2014), sehingga semantik yang dimaksud pada penelitian ini adalah melakukan identifikasi beberapa pola gestur tangan dalam satuan waktu yang membentuk sebuah makna (Bhaskoro, dkk, 2017) untuk digunakan sebagai masukan pengendali gerak dan aktifitas robot. 


\section{METODOLOGI PENELITIAN}

Pengendalian lengan robot beroda pemindah benda menggunakan semantik citra pada penelitian ini memiliki tiga sistem utama yaitu ekstraksi semantik citra, identifikasi semantik citra, dan pengendali gerak manuver robot serta lengan robot. Gambar 2 adalah ilustrasi tentang bagaimana hubungan ketiga sistem tersebut membentuk satu sistem yang utuh.

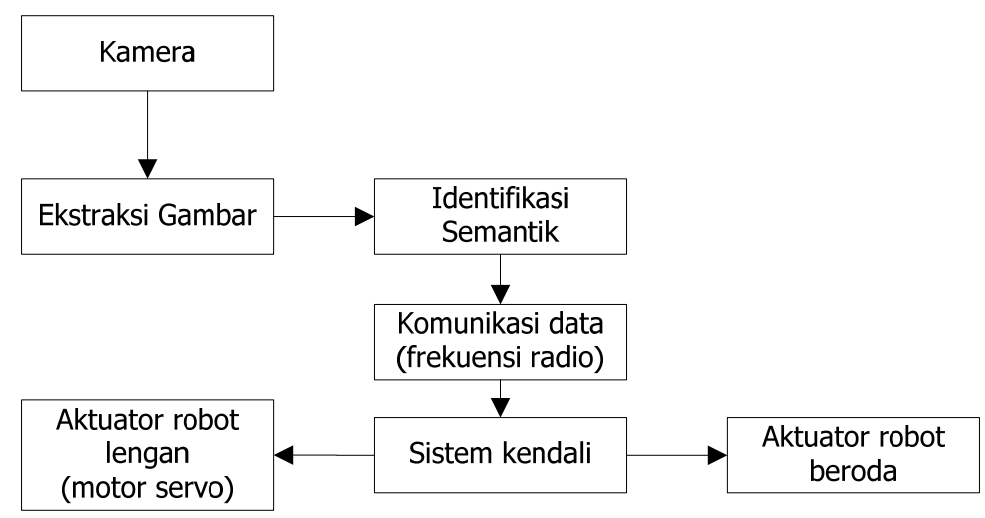

Gambar 2. Arsitektur Sistem

Tahapan yang dilakukan pada penelitian ini seperti yang terlihat pada Gambar 3 yaitu diawali dengan studi literatur untuk ekstraksi citra gestur tangan, studi literatur untuk teknik identifikasi semantik citra gestur tangan, studi literatur dari teknik pengendalian gerak manuver robot dan lengan robot. Keluaran dari ketiga studi literatur tersebut adalah usulan teknik yang paling sesuai untuk pengendalian lengan robot beroda pemindah benda menggunakan semantik citra.

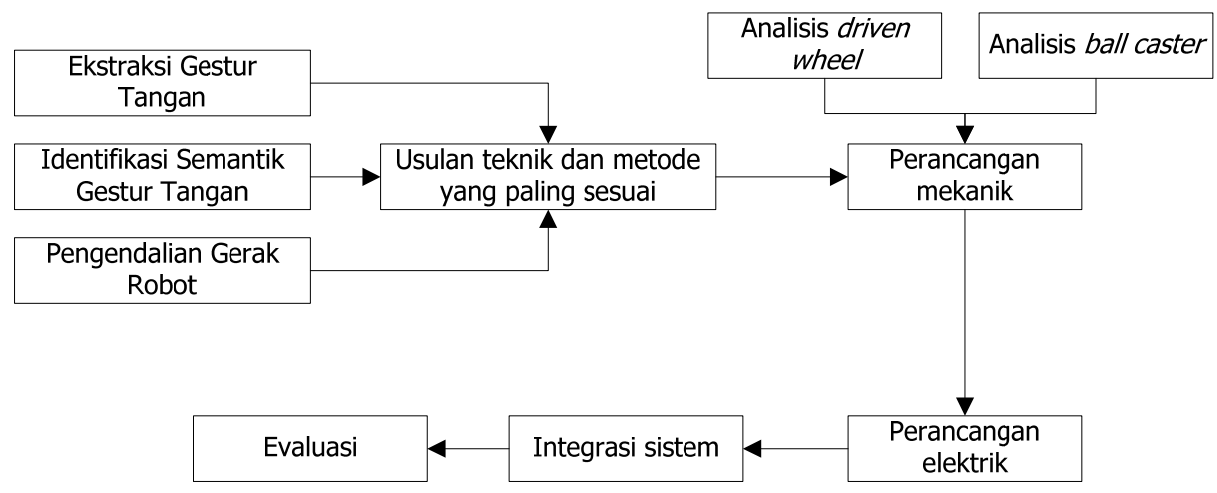

Gambar 3. Metodologi Penelitian

Tahapan selanjutnya adalah melakukan desain mekanik robot beroda dan lengannya. Setelah tahapan mekanik, aktifitas selanjutnya adalah membuat rangkaian elektrik yang diikuti dengan pembuatan program integrasi antara perangkat lunak dengan robot. Evaluasi dilakukan secara instrinsik yaitu black box terhadap kinerja identifikasi pengenalan semantik citra gestur tangan dan gerak manuver robot serta lengan robot. 


\subsection{Gambaran Sistem Perangkat Keras dan Perangkat Lunak}

Bagian perangkat keras pengendalian lengan robot beroda pemindah benda menggunakan instruksi semantik citra terdiri dari komponen penggerak, mikrokontroler, komponen elektrik, dan komponen mekanik. Komponen penggerak pada lengan robot menggunakan motor TowerPro MG995 Metal Gear Servo, selain itu digunakan juga Arduino Mega 2560 sebagai mikrokontroler untuk pengendali gerakan motor. Mikrokontroler Arduino Mega 2560 menjadi pusat komunikasi utama yang dapat menerima dan mengirim data dari dan ke software LabVIEW. Selain itu, mikrokontroler juga digunakan untuk menggerakkan aktuator robot dan menerima data dari sensor encoder. Ilustrasi sistem yang dikembangkan terlihat pada Gambar 4 berikut.

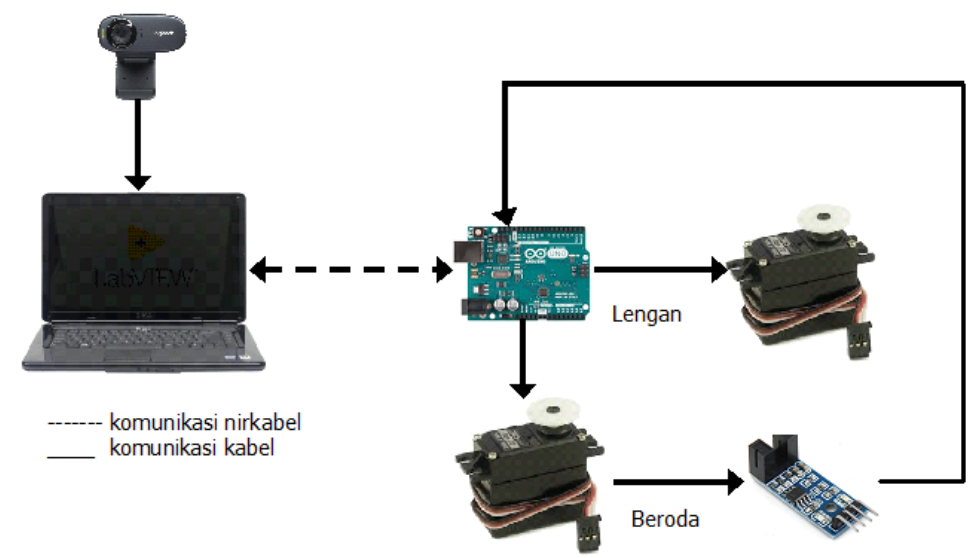

Gambar 4. Ilustrasi Sistem

Pengolahan citra yaitu ekstraksi citra dan identifikasi citra menggunakan bantuan software NI Lab-VIEW. Lab-VIEW tersebut terhubung dengan robot melalui komunikasi data nirkabel melalui jaringan frekuensi radio untuk memberikan instruksi gerak manuver robot serta lengan robot.

\subsection{Pergerakan Aktuator}

Pergerakan aktuator robot beroda pemindah benda menggunakan instruksi semantik citra ini dibagi menjadi dua yaitu program lengan robot dan program manuver robot beroda. Pergerakan manuver robot beroda ini diprogram berdasarkan perubahan posisi awal terhadap posisi akhir robot. Jika robot menerima perintah dan melakukan pergerakannya maka robot akan menghitung perubahan posisinya. Diagram alir proses pergerakan robot dapat dilihat pada Gambar 5 berikut.

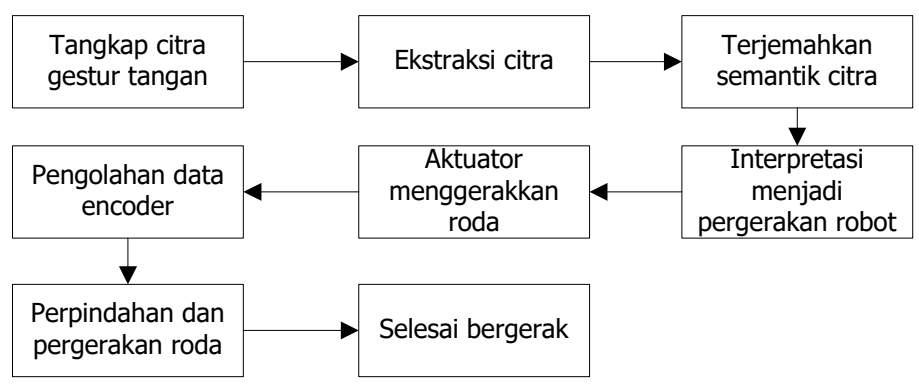

Gambar 5. Pergerakan Robot 
Robot bergerak melakukan perhitungan perubahan posisinya dengan menggunakan sensor rotary encoder (sensor encoder dan encoder disk). Sensor tersebut digunakan sebagai timbal balik dari pergerakan roda robot yang bekerja dengan cara mengirimkan pulsa apabila encoder disk berputar. Pulsa-pulsa tersebut nantinya akan diolah menjadi perpindahan jarak seperti yang ditunjukkan pada Gambar 6 berikut.

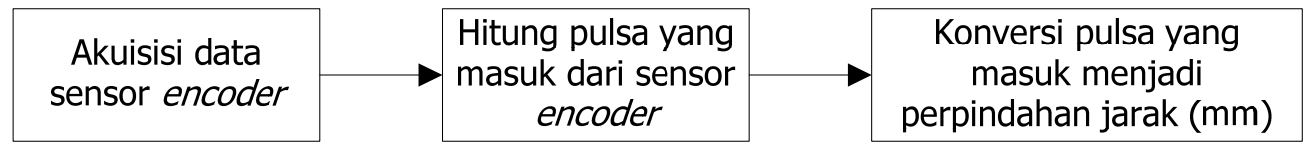

\section{Gambar 6. Pengolahan Data Sensor Rotary Encoder}

\subsection{Semantik Citra}

Semantik pada natural language processing yaitu proses yang mempelajari arti suatu kata dan bagaimana arti dari masing-masing kata tersebut menjelaskan secara utuh tentang makna pada sebuah kalimat yang lengkap (Girju, 2003). Sistem identifikasi citra gestur tangan pada sistem ini mengadopsi dari semantik pada natural language processing untuk menangkap makna gestur tangan yang ditangkap kamera. Proses capture gestur tangan manusia menggunakan Vision Assistant pada NI Vision Development Module (NI VDM) LabVIEW. Gambar 7 adalah program keseluruhan untuk pendeteksian citra gestur tangan manusia.

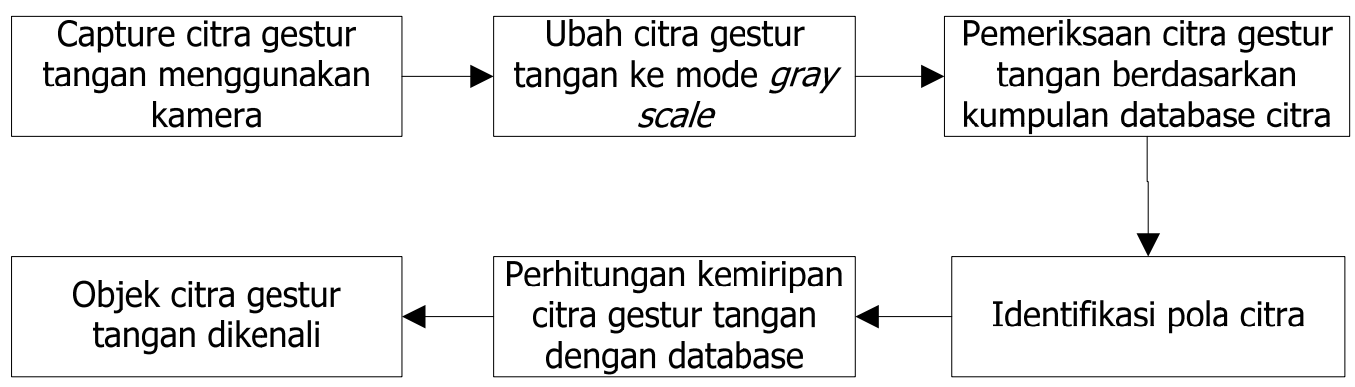

\section{Gambar 7. Identifikasi Citra Gestur Tangan}

Citra gestur tangan yang digunakan untuk mengendalikan gerak robot terdiri dari sebelas pola. Tabel 1 adalah sebelas gestur tangan dan instruksi untuk gerak robot yang digunakan pada penelitian ini. 
Pengendalian Gerak Robot menggunakan Semantik Citra Gestur Tangan Manusia

Tabel 1. Instruksi Gestur Tangan Manusia

\begin{tabular}{|c|c|c|c|}
\hline Gestur & Nama Gestur & Instruksi & Aktuator yang Aktif \\
\hline & A & Maju & $\begin{array}{lll} & \mathrm{A} \\
\mathrm{m} & \mathrm{B}\end{array}$ \\
\hline & Fist & Mundur & \begin{tabular}{lll|}
$\begin{array}{ll}\mathrm{B} \\
\mathrm{m}\end{array}$ & \\
$\mathrm{m}$ & \\
\end{tabular} \\
\hline & L Right & Berputar ke kanan & $\begin{array}{|lll|}\mathrm{D} & \mathrm{A} \\
\mathrm{m} & \mathrm{A} & \\
\end{array}$ \\
\hline & $\mathrm{L}$ & Berputar ke kiri & $\begin{array}{|lll|} & \text { B } & \\
& B & \\
\end{array}$ \\
\hline & $\mathrm{H}$ & $\begin{array}{l}\text { Waist berputar ke } \\
\text { kanan }\end{array}$ & $\therefore=$ \\
\hline & U & Waist berputar ke kiri & 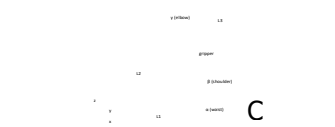 \\
\hline & $Y$ & Arm Home & $c=c$ \\
\hline & High five & Arm Lift & $C_{i} \quad+C$ \\
\hline & Hih five right & Arm Approach & $C \quad \ldots$ \\
\hline & C & Gripper release & $\therefore=$ \\
\hline 3 & G & Gripper grab & $\frac{-}{-}=$ \\
\hline $\begin{array}{c}\text { Keterangan aktuator } \\
\text { yang aktif }\end{array}$ & \multicolumn{3}{|c|}{$\begin{array}{l}\text { A: Roda berputar searah jarum jam } \\
\text { B: Roda berputar berlawanan arah jarum jam } \\
\text { C: Aktuator yang aktif }\end{array}$} \\
\hline
\end{tabular}

\subsection{Perancangan Mekanik}

Pada bagian desain robot dibedakan menjadi dua kategori yaitu desain untuk robot beroda dan desain untuk lengan robot. Gambar 8 pada gambar (a) adalah desain robot beroda menggunakan empat roda dan gambar (b) adalah desain dua driven whee/ ditambah satu ball caster. 


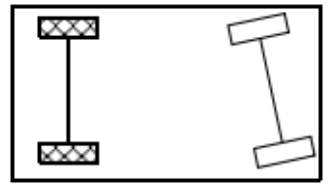

(a) Desain robot beroda menggunakan empat roda

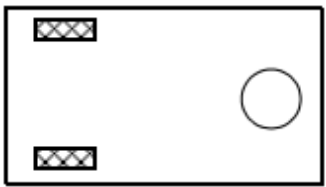

(b) Desain dua driven whee/ ditambah satu ball caster

\section{Gambar 8. Desain Robot Beroda menggunakan Empat Roda dan Dua Driven Wheel} Ditambah Satu Ball Caster

Berdasarkan Gambar 8 di atas driven wheel dengan satu ball caster (Gambar (b)) menjadi pilihan yang terbaik untuk digunakan pada penelitian ini karena memiliki kemudahan untuk melakukan manuver belok kiri dan belok kanan yang lebih baik dengan pengendalian aktuator yang lebih sederhana. Robot beroda dalam sistem ini memiliki konfigurasi dua driven whee/ yang digerakkan oleh motor servo Dynamixe/ sebagai penggeraknya dan ball caster untuk menyeimbangkan gerak manuver robot.

Robot ini juga memiliki dua layer yang berbahan akrilik dengan tebal $3 \mathrm{~mm}$ pada badannya. Layer pertama digunakan untuk menempatkan motor, rangkaian elektrik dan baterai. Sementara itu layer kedua yang ditopang oleh enam buah spacer terhadap layer pertama yang digunakan untuk menempatkan lengan robot. Gambar 9 adalah desain mekanik robot beroda yang dilakukan pada penelitian saat ini.

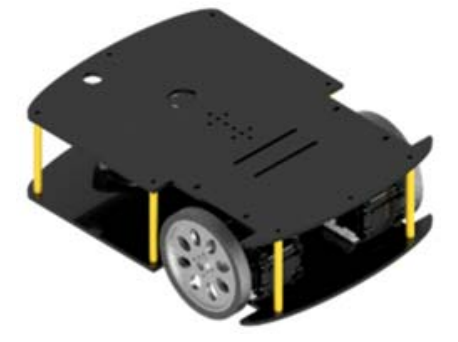

(a) Robot dua layer dengan tampak atas

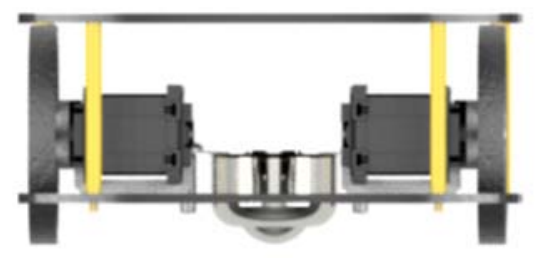

(b) Robot dua layer dengan tampak samping

\section{Gambar 9. Desain Mekanik Robot Beroda}

Desain pada bagian lengan robot keduanya memiliki tiga derajat ( 3 degress of freedom atau 3 DOF) kebebasan atau sendi dan dibedakan menjadi dua kategori yaitu (1) pergerakan sendi terhubung, (2) pergerakan sendi independen. Lengan robot dengan ketiga sendi bergerak secara independen dipilih karena memiliki fleksibilitas dalam gerakan dan gaya angkat yang lebih baik ketika dibandingkan dengan pergerakan sendi yang terhubung (Oktama, dkk, 2018).

Spesifikasi lengan robot 3 DOF tersebut terdapat pada waist, shoulder, dan elbow yang masing-masing digerakkan oleh Tower Pro MG 995 Metal Gear Servo. Selain itu, gripper juga merupakan bagian dari robot lengan sebagai End Effector dan pencengkram benda yang akan dipindahkan. Gripper tersebut juga digerakkan menggunakan motor servo yang sama. Gambar 10 adalah ilustrasi material-material pembangun kerangka lengan robot tersebut terdiri dari multifunctuion servo bracket (A), lacher bearing servo bracket (B), $U$ long shape servo bracket (C), L shape servo bracket (D), U short shape servo bracket $(\mathrm{E})$, dan gripper $(\mathrm{F})$. 


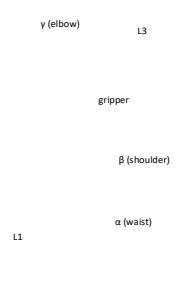

(a)

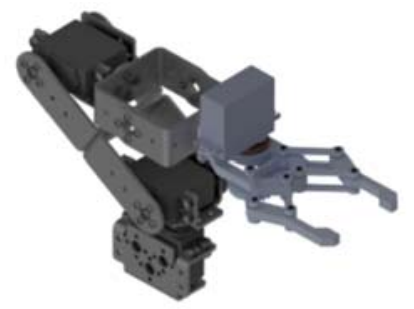

(b)

\section{Gambar 10. (a) Stick Diagram Robot Lengan dan (b) Desain Model Robot Lengan}

Aktualisasi mekanik pada sistem ini seperti yang terlihat pada Gambar 11 berikut.

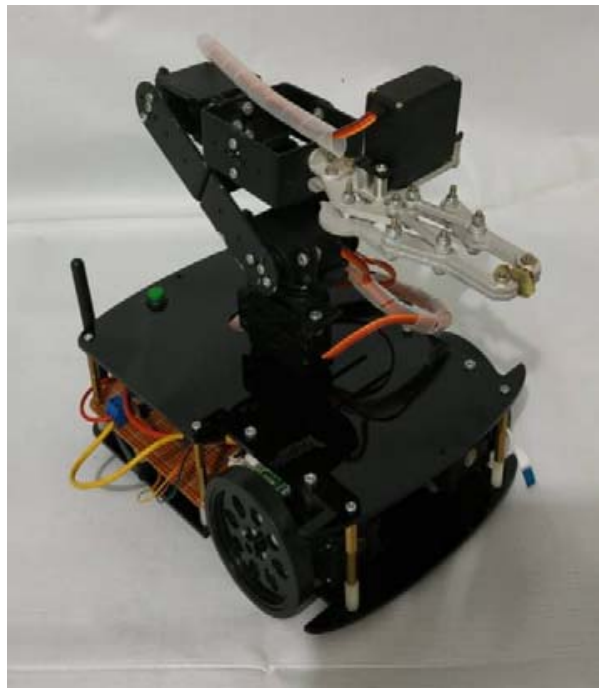

\section{Gambar 11. Aktualisasi Perancangan Mekanik}

\section{HASIL DAN ANALISIS}

\subsection{Skenario Pengujian Pergerakan}

Skenario ini dibuat supaya robot dapat mengambil dan menempatkan objek benda sesuai pada tempatnya. Selain itu, skenario ini juga dirancang berdasarkan perhitungan untuk memprediksikan pergerakan-pergerakan yang seharusnya dilakukan robot untuk mengambil dan menempatkan objek ke tempat yang telah disediakan, sehingga dapat memudahkan pengguna dalam memberikan perintah pada robot untuk mencapai tujuan yang dimaksud.

Skenario ini dimulai dari posisi awal robot pada arena pengujian yaitu koordinat $X, Y$ (200; 200) dengan titik referensi robot yaitu pada titik tengah antara kedua roda robot. Kemudian dilanjutkan dengan robot bergerak mendekati dan mengambil objek, dan selanjutnya robot mendekati rak penyimpanan sehingga objek dapat ditempatkan pada rak tersebut. Ilustrasi yang lebih rinci dapat diilustrasikan pada Gambar 12 di bawah ini. 


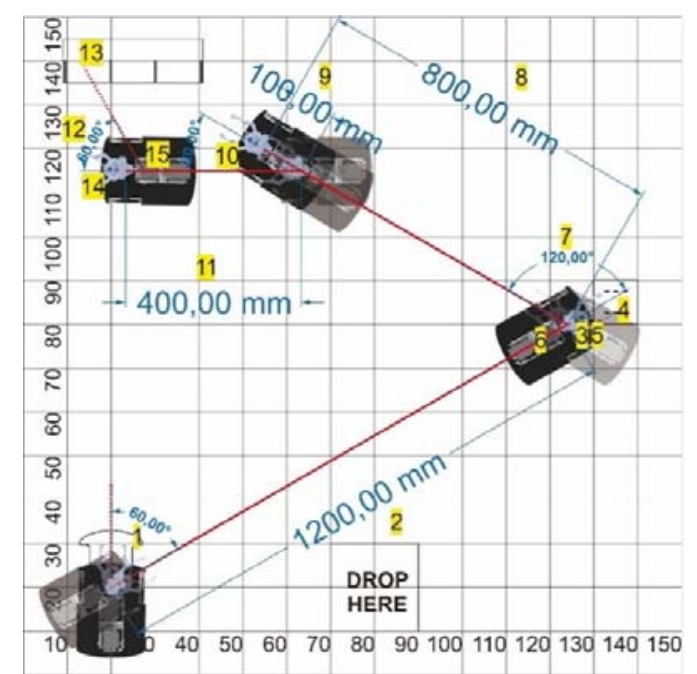

Gambar 12. Salah Satu Skenario Pengujian Pergerakan Robot

Pada Tabel 2 berikut ini adalah jenis perintah yang diberikan ke robot yaitu (b) tipe perintah yang harus dilakukan oleh robot, dan (c) banyaknya perintah yang diberikan itu adalah semantik citra gestur yang direkam untuk robot mengulangi kembali berdasarkan pola gestur tangan yang telah diidentifikasi.

Tabel 2. Instruksi Diberikan pada Robot

\begin{tabular}{|c|c|c|}
\hline $\begin{array}{c}\text { Perintah ke } \\
\text { (a) }\end{array}$ & $\begin{array}{c}\text { Jenis Perintah } \\
\text { (b) }\end{array}$ & $\begin{array}{c}\text { Banyaknya Perintah yang Diberikan } \\
\text { (c) }\end{array}$ \\
\hline 1. & Berputar ke kanan & 2 \\
\hline 2. & Maju & 6 \\
\hline 3. & Gripper release & 1 \\
\hline 4. & Arm approach & 1 \\
\hline 5. & Gripper grab & 1 \\
\hline 6. & Arm home & 4 \\
\hline 7. & Berputar ke kiri & 4 \\
\hline 8. & Maju & 1 \\
\hline 9. & Mundur & 1 \\
\hline 10. & Berputar ke kiri & 2 \\
\hline 11. & Maju & 6 \\
\hline 12. & Waist berputar ke kanan & 1 \\
\hline 13. & Arm lift & 1 \\
\hline 14. & Gripper release & 1 \\
\hline 15. & Arm home & \\
\hline
\end{tabular}

\subsection{Kinematika Langsung}

Kinematika langsung pada robot lengan digunakan pada saat robot melakukan gerakan arm approach untuk mendekatkan end effector ke objek, arm lift untuk menempatkan objek pada rak, serta arm home setelah dilakukannya arm approach maupun arm lift. 
Gambar 13 adalah ilustrasi model geometri lengan robot.

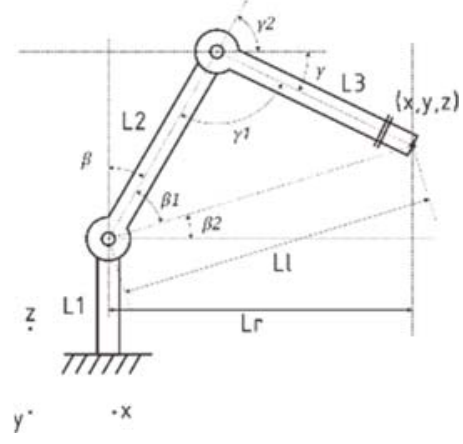

(a)

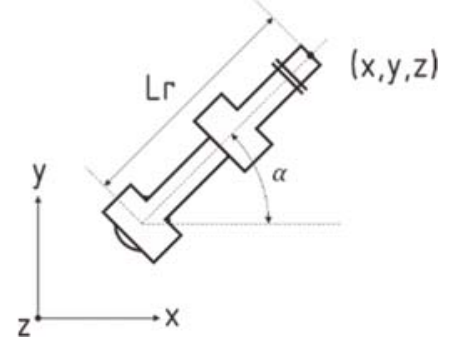

(b)

Gambar 13. (a) Geometri Robot Lengan Tampak Samping dan (b) Tampak Atas

\subsection{Hasil Pengujian Pendeteksian Gestur}

Pengujian ini dilakukan untuk mengetahui tingkat akurasi gestur tangan manusia yang berhasil diidentifikasi dengan dibatasi selama lima detik ketika melakukan capture gesturnya. Tabel 3 menunjukkan keberhasilan pendeteksian gestur yang dilakukan sebanyak sepuluh kali berdasarkan gestur instruksi yang terdapat pada Tabel 1 sebelumnya.

Tabel 3. Identifikasi Gestur Tangan

\begin{tabular}{|c|c|c|c|c|c|}
\hline No & Gestur & Gestur terdeteksi? & Match score & $\begin{array}{c}\text { Lama gestur } \\
\text { terdeteksi } \\
\text { (detik) }\end{array}$ & Error(\%) \\
\hline 1 & A & $10 / 10$ & 947 & 2 & 0 \\
\hline 2 & Fist & $10 / 10$ & 927 & 1 & 0 \\
\hline 3 & L right & $7 / 10$ & 871 & 1 & 30 \\
\hline 4 & $\mathrm{~L}$ & $9 / 10$ & 908 & 2 & 10 \\
\hline 5 & $\mathrm{H}$ & $9 / 10$ & 929 & 2 & 10 \\
\hline 6 & $\mathrm{U}$ & $9 / 10$ & 930 & 1 & 10 \\
\hline 7 & $\mathrm{Y}$ & $8 / 10$ & 876 & 5 & 20 \\
\hline 8 & High five & $10 / 10$ & 879 & 2 & 0 \\
\hline 9 & High five right & $10 / 10$ & 892 & 3 & 10 \\
\hline 10 & C & $9 / 10$ & 930 & 2 & 0 \\
\hline 11 & G & $10 / 10$ & 933 & 2 & 8,18 \\
\hline \multicolumn{7}{r}{}
\end{tabular}

Kesalahan rata-rata yang diperoleh sebesar 8,18\%. Kesalahan terbesar terjadi pada pembacaan gestur $L$ right yaitu sebesar $30 \%$. Hal tersebut disebabkan pencahayaan yang berbeda dengan template yang digunakan, jarak tangan dengan webcam, dan gambar latar. Sehingga teknik yang dibutuhkan untuk perbaikan pada future work berkaitan dengan kesalahan yang terjadi adalah penggunaan multi-kamera dengan sudut pandang gestur tangan yang terlihat dari depan dan samping.

\subsection{Hasil Pengujian Gestur Random User}

Pengujian ini dilakukan untuk mengetahui tingkat akurasi gestur tangan manusia dari empat orang yang berbeda (orang-orang yang gestur tangannya tidak pernah direkam ke dalam sistem pada tahapan training data), masing-masing menguji 11 macam gestur sebanyak lima kali sehingga data yang diuji sebanyak 220 data seperti yang ditampilkan pada Tabel 4. 
Sama seperti pengujian sebelumnya (pengujian yang ditampilkan pada Tabel 3, pendeteksian gestur dibatasi selama lima detik.

Tabel 4. Identifikasi Gestur Tangan Random User

\begin{tabular}{|c|c|c|c|}
\hline No. & Gestur & Terdeteksi / Percobaan & Error (\%) \\
\hline 1 & A & $15 / 20$ & 25 \\
\hline 2 & Fist & $13 / 20$ & 35 \\
\hline 3 & L right & $17 / 20$ & 15 \\
\hline 4 & L & $9 / 20$ & 55 \\
\hline 5 & U & $20 / 20$ & 0 \\
\hline 6 & Y & $15 / 20$ & 25 \\
\hline 7 & High five & $15 / 20$ & 25 \\
\hline 8 & High five right & $11 / 20$ & 45 \\
\hline 9 & C & $20 / 20$ & 0 \\
\hline 10 & G & $17 / 20$ & 15 \\
\hline 11 & \multicolumn{2}{|r|}{ Rata-rata error } & 5 \\
\hline \multicolumn{2}{r}{} \\
\hline
\end{tabular}

Pada pengujian random user yang dilakukan sebanyak 220 kali dengan empat orang berbeda, kesalahan rata-rata sebesar $22,27 \%$. Kesalahan terbesar terjadi pada pembacaan gestur $\mathrm{L}$ sebesar $55 \%$, sedangkan kesalahan terkecil terjadi pada gestur $\mathrm{H}$ dan High Five Right yaitu sebesar $0 \%$. Hal ini disebabkan oleh beberapa faktor yaitu bentuk tangan setiap orang berbeda-beda ketika ditangkap oleh kamera, terjadi getaran atau selalu bergerak tangannya, pencahayaan yang berbeda saat pengambilan data, jarak tangan ketika pengambilan data, serta gambar latar. Sehingga teknik yang dibutuhkan untuk perbaikan pada future work berkaitan dengan kesalahan yang terjadi adalah penggunaan lampu untuk melakukan capture gestur tangan manusia.

\subsection{Hasil Pengujian Manuver Robot}

Pengujian ini dilakukan dengan cara membandingkan pergerakan aktual dengan pergerakan pada sistem (pergerakan yang telah dirancang dalam program robot). Manuver robot ini terdiri dari empat pergerakan yaitu; maju, mundur, berputar ke kiri, dan berputar ke kanan. Pengujian ini dilakukan secara berkelanjutan dengan tidak mengubah posisi terakhir dari pengujian sebelumnya dan kemudian posisi dari robot ditentukan dengan cara mendefinisikan koordinat $\mathrm{x}$ dan y dalam satuan milimeter empat titik ujung dari robot yaitu; titik kiri atas, kanan atas, kiri bawah, dan kanan bawah. Namun untuk pengujian robot berputar ke kiri dan ke kanan hanya didefinisikan titik ujung poros roda robot dalam koordinat $\mathrm{x}$ dan $\mathrm{y}$. Pada pengujian pergerakan maju dilakukan dengan posisi awal titik kiri atas, kanan atas, kiri bawah, dan kanan bawah secara berurutan adalah $(30 ; 27,6)$, $(46 ; 27,6),(30 ; 9,2),(46 ; 9,2)$. Tabel 5 menunjukkan hasil dari lima pengujian untuk pergerakan maju robot yang telah dilakukan.

Tabel 5. Data Pengujian Gerakan Maju

\begin{tabular}{|c|c|c|c|c|}
\hline \multirow{2}{*}{ Pengujian ke- } & \multicolumn{4}{|c|}{ Posisi titik ujung robot (x;y) } \\
\cline { 2 - 5 } & Kiri atas & Kanan atas & Kiri bawah & Kanan bawah \\
\hline 1 & $(30 ; 48,3)$ & $(46 ; 48,2)$ & $(30 ; 30)$ & $(46 ; 29,9)$ \\
\hline 2 & $(30,2 ; 69)$ & $(46,2 ; 68,8)$ & $(30,1 ; 50,7)$ & $(46 ; 50,4)$ \\
\hline 3 & $(30,4 ; 90,5)$ & $(46,3 ; 90,3)$ & $(30,2 ; 72,1)$ & $(46,2 ; 72)$ \\
\hline 4 & $(30,3 ; 111)$ & $(46,3 ; 111)$ & $(30,4 ; 92,6)$ & $(46,4 ; 92,7)$ \\
\hline 5 & $(30 ; 131,5)$ & $(46 ; 131,9)$ & $(30,5 ; 113,3)$ & $(46,4 ; 113,6)$ \\
\hline
\end{tabular}


Tabel 6 merupakan pengujian pergerakan mundur dilakukan dengan posisi awal titik kiri atas, kanan atas, kiri bawah, dan kanan bawah secara berurutan adalah $(30 ; 78),(46 ; 78)$, $(30 ; 59,6),(46,4 ; 59,6)$.

Tabel 6. Data Pengujian Gerakan Mundur

\begin{tabular}{|c|c|c|c|c|}
\hline \multirow{2}{*}{ Pengujian ke- } & \multicolumn{4}{|c|}{ Posisi titik ujung robot (x;y) } \\
\cline { 2 - 5 } & Kiri atas & Kanan atas & Kiri bawah & Kanan bawah \\
\hline 1 & $(30 ; 67,7)$ & $(45,9 ; 67,5)$ & $(29,7 ; 49,5)$ & $(45,7 ; 49,2)$ \\
\hline 2 & $(29,7 ; 57,1)$ & $(45,7 ; 56,8)$ & $(29,3 ; 38,8)$ & $(45,3 ; 38,6)$ \\
\hline 3 & $(29,4 ; 46,7)$ & $(45,4 ; 46,4)$ & $(29,1 ; 28,3)$ & $(45,1 ; 28,1)$ \\
\hline 4 & $(29,1 ; 36,4)$ & $(45,1 ; 36,1)$ & $(28,7 ; 18,1)$ & $(44,6 ; 17.8)$ \\
\hline 5 & $(28,8 ; 25,9)$ & $(44,8 ; 25,2)$ & $(27,9 ; 7,6)$ & $(43,9 ; 6,8)$ \\
\hline
\end{tabular}

Tabel 7 merupakan pengujian pergerakan berputar ke arah kiri dilakukan dengan posisi awal titik ujung poros roda robot kiri dan kanan secara berurutan adalah $(30 ; 36),(46 ; 36)$.

Tabel 7. Data Pengujian Pergerakan Berputar Arah Kiri

\begin{tabular}{|c|c|c|c|}
\hline \multirow{2}{*}{ Pengujian ke- } & Titik ujung poros roda robot $(\mathbf{x}, \mathbf{y})$ & \multirow{2}{*}{ Error $(\%)$} \\
\cline { 2 - 3 } & Kiri & $(44,9 ; 40,4)$ & 8,97 \\
\hline 1 & $(31,5 ; 31,8)$ & $(40,8 ; 44,1)$ & 18.8 \\
\hline 2 & $(34,8 ; 29)$ & $(36,1 ; 44,4)$ & 8 \\
\hline 3 & $(39,1 ; 28,6)$ & $(31,1 ; 42,2)$ & 16,6 \\
\hline 4 & $(43,1 ; 30,5)$ & $(30.6 ; 39,2)$ & 71.8 \\
\hline 5 & $(45,7 ; 33,7)$ & & 14,36 \\
\hline \multicolumn{3}{|r|}{ Jumlah error $(\%)$} & \\
\hline
\end{tabular}

Tabel 8 merupakan pengujian pergerakan berputar ke arah kanan dilakukan dengan posisi awal titik kiri atas, kanan atas, kiri bawah, dan kanan bawah secara berurutan adalah $(30 ; 40),(46 ; 40),(30 ; 21,7),(46 ; 21,7)$ serta posisi titik tengah roda robot kiri dan kanan secara berurutan $(30 ; 36),(46 ; 36)$.

Tabel 8. Data Pengujian Pergerakan Berputar Arah Kiri

\begin{tabular}{|c|c|c|c|}
\hline \multirow{2}{*}{ No. } & Titik Ujung Poros Roda Robot $(\mathbf{x}, \mathbf{y})$ & \multirow{2}{*}{ Error (\%) } \\
\cline { 2 - 4 } & Kiri & Kanan & 11.3 \\
\hline 1. & $(316 ; 406)$ & $(448 ; 319)$ & 4,97 \\
\hline 2. & $(347 ; 433)$ & $(415 ; 288)$ & 6,3 \\
\hline 3. & $(389 ; 440)$ & $(370 ; 280)$ & 6,3 \\
\hline 4. & $(428 ; 422)$ & $(328 ; 297)$ & 4.43 \\
\hline 5. & $(453 ; 385)$ & $(302 ; 330)$ & 33.3 \\
\hline \multicolumn{2}{|r|}{ Jumlah error $(\%)$} & 6.66 \\
\hline
\end{tabular}

\subsection{Hasil Pengujian Sudut Lengan Robot}

Pengujian sudut lengan robot dilakukan untuk mengetahui ketepatan sudut saat melakukan pergerakan yaitu dengan cara membandingkan sudut aktual yang terjadi pada joint-joint dengan sudut yang dihasilkan dari program robot yang dirancang. Pergerakan lengan robot ini terdiri dari waist berputar ke kiri serta ke kanan, arm approach, dan arm lift dan kemudian mendefinisikan posisi end effector dalam koordinat $\mathrm{x}, \mathrm{y}$, dan $\mathrm{z}$ dari hasil pengujian yang dilakukan. 
Pada pegujian pergerakan waist berputar ke kiri, sudut awal waist berada pada sudut $86^{\circ}$. Pengujian ini dilakukan secara berkelanjutan dengan tidak mengubah sudut terakhir dari pengujian sebelumnya. Namun saat pengujian ke-sembilan, dimulai kembali dari sudut $86^{\circ}$ karena batasan kemampuan servo yang digunakan. Tabel 9 menunjukkan hasil pengujian pergerakan waist berputar ke kiri.

Tabel 9. Data Pengujian Pergerakan Berputar Arah Kiri

\begin{tabular}{|c|c|c|c|}
\hline No. & Besarnya Sudut & Output Koordinat End Effector & Error (\%) \\
\hline 1. & $94^{\circ}$ & $(-9 ; 128,8 ; 182,5)$ & 20 \\
\hline 2. & $105^{\circ}$ & $(-33,4 ; 124,7 ; 182,5)$ & 10 \\
\hline 3. & $115^{\circ}$ & $(-54,5 ; 117 ; 182,5)$ & 0 \\
\hline 4. & $125^{\circ}$ & $(-74 ; 105,7 ; 182,5)$ & 0 \\
\hline 5. & $135^{\circ}$ & $(-91,3 ; 91,3 ; 182,5)$ & 0 \\
\hline 6. & $145^{\circ}$ & $(-105,7 ; 74 ; 182,5)$ & 20 \\
\hline 7. & $157^{\circ}$ & $(-118,8 ; 50,4 ; 182,5)$ & 0 \\
\hline 8. & $167^{\circ}$ & $(-125,8 ; 29 ; 182,5)$ & 40 \\
\hline 9. & $91^{\circ}$ & $(-2,2 ; 129 ; 182,5)$ & 20 \\
\hline 10. & $103^{\circ}$ & $(-29 ; 125,8 ; 182,5)$ & 11 \\
\hline \multicolumn{2}{|r|}{ Rata-rata error $(\%)$} \\
\hline
\end{tabular}

Tabel 10 berikut ini adalah hasil pengujian pergerakan waist berputar ke kanan.

Tabel 10. Data Pengujian Pergerakan Berputar Arah Kanan

\begin{tabular}{|c|c|c|c|}
\hline No. & Besarnya Sudut & Output Koordinat End Effector & Error(\%) \\
\hline 1. & $79^{\circ}$ & $(24,6 ; 126,7 ; 182,5)$ & 30 \\
\hline 2. & $67^{\circ}$ & $(50,4 ; 118,8 ; 182,5)$ & 20 \\
\hline 3. & $58^{\circ}$ & $(68,3 ; 109,5 ; 182,5)$ & 10 \\
\hline 4. & $49^{\circ}$ & $(84,7 ; 97,4 ; 182,5)$ & 10 \\
\hline 5. & $39^{\circ}$ & $(100,3 ; 81,2 ; 182,5)$ & 0 \\
\hline 6. & $27^{\circ}$ & $(115 ; 58,6 ; 182,5)$ & 0 \\
\hline 7. & $17^{\circ}$ & $(123,4 ; 37,7 ; 182,5)$ & 0 \\
\hline 8. & $7^{\circ}$ & $(128,1 ; 15,7 ; 182,5)$ & 20 \\
\hline 9. & $78^{\circ}$ & $(26,8 ; 126,2 ; 182,5)$ & 10 \\
\hline 10. & $69^{\circ}$ & $(46,2 ; 120,5 ; 182,5)$ & 12 \\
\hline \multicolumn{2}{|c|}{ Rata-rata error $(\%)$} & \\
\hline
\end{tabular}

Pada pengujian pergerakan arm approach, diawali dengan posisi waist berada pada sudut $86^{\circ}$, shoulder pada sudut $55^{\circ}$, dan elbow pada sudut $75^{\circ}$. Pengujian ini dilakukan secara berulang sebanyak sepuluh kali percobaan. Tabel 11 menunjukkan hasil dari sepuluh pengujian pergerakan arm approach.

Tabel 11. Pengujian Arm Approach

\begin{tabular}{|c|c|c|c|c|c|}
\hline \multirow{2}{*}{ No } & \multicolumn{2}{|c|}{ Besarnya Sudut } & \multirow{2}{*}{ Output Koordinat End Effector } & \multicolumn{2}{c|}{ Error (\%) } \\
\cline { 2 - 3 } \cline { 5 - 6 } & Shoulder & Elbow & Shoulder & Elbow \\
\hline 1. & $46^{\circ}$ & $108^{\circ}$ & $(12,3 ; 175,8 ; 11,3)$ & 16,36 & 6,09 \\
\hline 2. & $44^{\circ}$ & $110^{\circ}$ & $(11,5 ; 164,6 ; 2)$ & 20 & 4,35 \\
\hline 3. & $45^{\circ}$ & $109^{\circ}$ & $(11,9 ; 170,3 ; 6,5)$ & 18,18 & 5,22 \\
\hline 4. & $44^{\circ}$ & $109^{\circ}$ & $(11,8 ; 168 ; 3,6)$ & 20 & 5,22 \\
\hline 5. & $45^{\circ}$ & $109^{\circ}$ & $(10,7 ; 152,4 ; 82)$ & 18,18 & 5,22 \\
\hline 6. & $44^{\circ}$ & $109^{\circ}$ & $(11,8 ; 168 ; 3,6)$ & 20 & 5,22 \\
\hline 7. & $44^{\circ}$ & $110^{\circ}$ & $(11,5 ; 164,6 ; 2)$ & 20 & 4,35 \\
\hline 8. & $45^{\circ}$ & $110^{\circ}$ & $(11,7 ; 166,8 ; 4,9)$ & 18,18 & 4,35 \\
\hline
\end{tabular}




\begin{tabular}{|c|c|c|c|c|c|}
\hline \multirow{2}{*}{ No } & \multicolumn{2}{|c|}{ Besarnya Sudut } & \multirow{2}{*}{ Output Koordinat End Effector } & \multicolumn{2}{c|}{ Error(\%) } \\
\cline { 2 - 4 } \cline { 4 - 5 } & Shoulder & Elbow & & Shoulder & Elbow \\
\hline 9. & $44^{\circ}$ & $110^{\circ}$ & $(11,5 ; 164,6 ; 2)$ & 20 & 4,35 \\
\hline 10. & $45^{\circ}$ & $110^{\circ}$ & $(11,7 ; 166,8 ; 4,9)$ & 18,18 & 4,35 \\
\hline \multicolumn{3}{|c|}{ Rata-rata error $(\%)$} & 18,9 & 4,87 \\
\hline
\end{tabular}

Pada pengujian pergerakan arm lift, diawali dengan posisi waist berada pada sudut $86^{\circ}$, shoulder pada sudut $55^{\circ}$, dan elbow pada sudut $75^{\circ}$. Pengujian ini dilakukan secara berulang dengan banyaknya sepuluh kali percobaan. Tabel 12 menunjukkan hasil dari sepuluh pengujian pergerakan arm lift.

Tabel 12. Pengujian Arm Lift

\begin{tabular}{|c|c|c|c|c|c|}
\hline \multirow{2}{*}{ No } & \multicolumn{2}{|c|}{ Besarnya Sudut } & \multirow{2}{*}{ Output Koordinat End Effector } & \multicolumn{2}{c|}{ Error (\%) } \\
\cline { 2 - 5 } & Shoulder & Elbow & & Shoulder & Elbow \\
\hline 1. & $44^{\circ}$ & $65^{\circ}$ & $(19,6 ; 280,2 ; 124,1)$ & 20 & 13,33 \\
\hline 2. & $43^{\circ}$ & $65^{\circ}$ & $(19,6 ; 280,1 ; 119,2)$ & 21,81 & 13,33 \\
\hline 3. & $42^{\circ}$ & $64^{\circ}$ & $(19,7 ; 281,3 ; 117,8)$ & 23,64 & 14,67 \\
\hline 4. & $44^{\circ}$ & $64^{\circ}$ & $(19,7 ; 281,6 ; 127,7)$ & 20 & 14,67 \\
\hline 5. & $42^{\circ}$ & $64^{\circ}$ & $(19,7 ; 281,3 ; 117,8)$ & 23,64 & 14,67 \\
\hline 6. & $43^{\circ}$ & $65^{\circ}$ & $(19,6 ; 280,1 ; 119,2)$ & 21,81 & 13,33 \\
\hline 7. & $43^{\circ}$ & $64^{\circ}$ & $(19,7 ; 281,5 ; 122,8)$ & 21,81 & 14,67 \\
\hline 8. & $44^{\circ}$ & $64^{\circ}$ & $(19,7 ; 281,6 ; 127,7)$ & 20 & 14,67 \\
\hline 9. & $43^{\circ}$ & $64^{\circ}$ & $(19,7 ; 281,5 ; 122,8)$ & 21,81 & 14,67 \\
\hline 10. & $44^{\circ}$ & $64^{\circ}$ & $(19,7 ; 281,6 ; 127,7)$ & 20 & 14,67 \\
\hline \multicolumn{7}{|r|}{ Rata-rata error $(\%)$} & 21,45 & 14,27 \\
\hline
\end{tabular}

\subsection{Hasil Pengujian Pengambilan dan Penempatan Objek Benda}

Pengujian ini dilakukan untuk mengetahui keberhasilan robot untuk mengambil objek dari tempatnya ke penyimpanan. Pengujian ini juga dilakukan berdasarkan skenario pengambilan dan penempatan objek benda seperti yang telah dijelaskan sebelumnya. Tabel 13 menunjukkan hasil dari pengujian pengambilan dan penempatan objek benda.

Tabel 13. Pengujian Pengembalian dan Penempatan Objek

\begin{tabular}{|c|c|c|c|}
\hline Pengujian ke- & Terambil & Terpindahkan & Keterangan \\
\hline 1 & Tidak & Tidak & Robot tidak cukup dekat dengan objek. \\
\hline 2 & Ya & Ya & Berhasil \\
\hline 3 & Ya & Tidak & Robot tidak cukup dekat dengan rak. \\
\hline 4 & Tidak & Tidak & Robot tidak cukup dekat dengan objek. \\
\hline 5 & Ya & Ya & Berhasil \\
\hline 6 & Ya & Tidak & Robot tidak cukup dekat dengan rak. \\
\hline 7 & Ya & Tidak & Robot tidak cukup dekat dengan rak. \\
\hline 8 & Tidak & Tidak & Robot tidak cukup dekat dengan objek. \\
\hline 9 & Tidak & Tidak & Robot tidak cukup dekat dengan objek. \\
\hline 10 & Ya & Ya & Berhasil \\
\hline
\end{tabular}

Bedasarkan Tabel 13 di atas robot dapat mengambil objek benda enam kali dari sepuluh kali percobaan, sehingga memiliki tingkat kesalahan $40 \%$ dalam pengambilan. Sementara itu objek berhasil dipindahkan sebanyak tiga kali dari enam kali percobaan, sehingga memiliki tingkat kesalahan $50 \%$ dalam memindahkan (penempatan). Secara keseluruhan robot dapat mengambil dan menempatkan objek tiga kali dari sepuluh kali percobaan, sehingga memiliki tingkat kesalahan sebesar $70 \%$. Kesalahan tersebut disebabkan oleh pergerakan robot 
beroda yang tidak memiliki pengendalian atau referensi, sehingga pergerakan robot tidak sesuai skenario.

\section{KESIMPULAN}

Berdasarkan pengujian yang dilakukan terhadap sistem yang telah dikembangkan dapat disimpulkan yaitu: pendeteksian gestur menggunakan NI VISION LabVIEW memiliki keberhasilan sebesar $91,82 \%$ untuk pengguna yang telah direkam gesturnya pada tahapan training data dan $77,73 \%$ untuk random user. Pergerakan manuver maju robot memiliki error dengan rata-rata sebesar 4,125\%, mundur sebesar 4,85\%, berputar ke arah kiri sebesar $14,36 \%$, dan berputar ke arah kanan sebesar 6,66\%. Pengambilan dan pemindahan objek menggunakan robot ini memiliki tingkat error sebesar $70 \%$.

\section{DAFTAR RUJUKAN}

Arifin, M. A. S. (2017). Rancang Bangun Prototype Robot Lengan Menggunakan Flex Sensor dan Accelerometer Sensor pada Lab Mikrokontroler STMIK Musirawas. ILKOM Jurnal IImiah, 9(3), 255-261.

Bhaskoro, S. B., Akbar, S., \& Supangkat, S. H. (2017). Extracting Important Sentences for Public Health Surveillance Information from Indonesian Medical Articles. International Conference on ICT for Smart Society (ICISS), (pp. 1-7).

Girju, R. (2003). Automatic detection of causal relations for Question Answering. ACL 2003 workshop on Multilingual summarization and question answering, (pp. 76-83).

Oktama, R., Maulana, R., \& Setyawan, G. E. (2018). Implementasi Robot Lengan Pemindah Barang 3 DOF Menggunakan Metode Inverse Kinematics. Jurnal Pengembangan Teknologi Informasi dan IImu Komputer, 2(8), 2810-2861.

Riaz, M., \& Girju, R. (2014). In-depth Exploitation of Noun and Verb Semantics to Identify Causation in Verb-Noun Pairs. The 15th Annual Meeting of the Special Interest Group on Discourse and Dialogue, (pp. 161-170).

Syed, A., Agasbal, Z. T. H., Melligeri, T., \& Gudur, B. (2012). Flex Sensor Based Robotic Arm Controller Using Micro Controller. Journal of Software Engineering and Applications, 5(5), 364-366. 